\title{
2 \\ The Political Setting of the Amherst Embassy
}

China's worldview had a major impact on the fortunes of the Amherst Embassy and it is important to understand this context for framing what was a significant diplomatic event in Anglo-Chinese relations in the opening decades of the nineteenth century. British interest in China at this time was based solely on trade and profit and not on territory or conquest, unlike its activities in India and elsewhere around the globe. The dispatch of the Amherst Embassy represented a genuine British endeavour to negotiate a better trade relationship at Canton and, in the event that these negotiations were successful, to secure further trade concessions from China.

The Amherst Embassy, like its predecessor the Macartney Embassy of 1793, was received at the Qing court within the context of the traditional tributary system that governed Chinese international relations. The specific problems at Canton that initiated the dispatch of both embassies were caused by the constraints of the 'Canton trade system' established by the Qing court by 1760 to both contain and govern expanding European trade with China. An understanding of this system, as well as the principles and practices enshrined in the Westphalian system of European diplomacy that governed British diplomatic actions, provides a vital context for the approach, activities and reactions of the Amherst Embassy in its efforts to negotiate with the Qing court. Brief outlines of the British East India Company (henceforth referred to as 'the Company'), the political-military environment of the Pearl River (on which Canton was situated) in the 
immediate period before the Amherst Embassy, as well as the importance of the growth of British nationalism at this time, are also included to provide a wider context for an understanding of the embassy.

\section{The Tribute System}

The 'tribute system' has been the subject of extensive scholarship and debate by Western historians. ${ }^{1}$ General references define it as 'a system under which foreign states submitted to Chinese suzerainty by exchanging gifts for trading privileges in China', where the emperor, designated the Son of Heaven, demanded 'submission from those outside the empire who were considered barbarians' (Perkins, 1999, p. 533). Foreign countries wishing to trade with China sent missions to the Chinese capital to submit to the sovereignty of the Chinese emperor, acknowledged by performing the kowtow before him. In return, permission was granted for the right to trade at stipulated times and designated ports along the Chinese coast (Perkins, 1999, p. 533). The tribute system applied to all of China's external relations but for the purposes of this study of the Amherst Embassy, the focus is on maritime Southeast Asia, the direction from which early Western maritime traders approached China.

O. W. Wolters, in his seminal study of Sino-Malay relations in the fourteenth century, explained the manner in which the Chinese emperor was perceived as the Son of Heaven that situated him above all other earthly sovereigns (1970, pp. 24-25). The emperor's efficacy was due to his being the repository of $d e$ (moral power or 'superior virtue') that functioned to legitimise his authority as well as defining Chinese cultural superiority and positioning him above all other sovereigns, who by definition were considered inferior or barbarians. Chinese, as well as barbarians, were attracted to the concept of $d e .^{2}$ Foreign rulers drawn to de sent periodic gifts or tribute brought by envoys in 'acknowledgment of their cultural homage'

1 References on the 'tribute system' are numerous and include Andornino (2006), Fairbank (1942), Fairbank and Teng (1941) and Hevia (1995). Wills (2009) argued that, by the time of the Qing dynasty, the tributary system applied only to a handful of vassal states such as 'Korea, Ryukyu, Vietnam, and Siam' (p. 182). Nevertheless, for the purposes of this brief summary, reference made to the longer historical tradition of the tribute system serves to illustrate its cultural context beyond its economic aspect and is useful for a deeper appreciation of its role in Chinese external relations.

2 Staunton's (1821) translation of the Narrative of the Chinese embassy to the Khan of the Tourgouth Tartars, in the years 1712, 13, 14, \& 15 refers to the Khan being attracted to China: 'I have admired from afar your heavenly court, and the most excellent and most resplendent virtues of your Emperor; the contemplation of such sublime perfection made me wish to draw near, so as actually to behold the heavenly countenance' (p. 204). 
to the Chinese emperor, thus ensuring order and security built up through a system of alliances. ${ }^{3}$ The tribute system rested on an ideological platform that distinguished between civilisation and barbarism where compliance with correct ritual behaviour was essential for the tribute system's operation. The historian Simon Leys stressed the importance of rites in the Confucian order where 'the true cohesion of a society is secured not through legal rules but through ritual observances' (1997, p. xxv). Wolters (1970) quoted Confucius on the nature of de to explain its function in the context of ensuring order in international relations:

If such a [well-ordered] state of affairs exists, yet the people of faroff lands still do not submit, then the ruler must attract them by enhancing the prestige $[d e]$ of his culture; and when they have been truly attracted, he contents them. And where there is contentment there will be no upheavals. (p. 25)

The concept of submission and being attracted to embrace Chinese culture was an anathema to the British and, it will be seen, the antithesis of Westphalian principles. But Wolters explains that the verification of the power of $d e$ and its efficacy to attract vassal princes made possible the formation of an extensive trade network founded on the maritime trade routes to China. Emperors who ruled 'all under heaven' showed compassion to the men who had 'travelled from afar' and bestowed protection and titles on vassal princes who returned to their homelands with their right to rule legitimised by the Chinese emperor and transformed due to their contact with Chinese civilisation (Cranmer-Byng, 1962, p. 6). In this way, peace resulting from the tribute system operated as an external network of control, whereby security and stability reigned in the distant western oceans as Chinese influence spread out in a series of concentric circles to embrace the outlying petty states of maritime Southeast Asia (Hamashita, 1997).

The tributary system has been described by Richard Smith (2013, pp. 79-81) as a highly sophisticated, remarkably flexible and perfectly rational system of managing the world. Its specific nature changed in response to different historical forces impacting on China at different times; for example, during the Yuan dynasty, the power of de was replaced by military force. The historian Anthony Reid (1996, p. 17) wrote that in keeping with the Mongol's view as 'world conquerors', submission to the emperor was enforced in Java in 1293 through the dispatch of 20,000 soldiers by Kublai Khan to punish

3 These are Alexander Woodside's (1971, p. 235) words used in the context of the Vietnamese tributary system, but are applicable to this context. 
King Kertanegara for 'his insolence'. The tribute system was restructured at the time of the Ming dynasty by the Hongwu emperor (r. 1368-1398) who restricted foreign maritime trade to official tribute missions and prohibited all private overseas trade (Wang, 2003, p. 53).

The incoming Qing dynasty in the seventeenth century adopted the essential tenets of the Ming policy, but with the consolidation of Qing rule in the early 1680s the Kangxi emperor (r. 1661-1722) issued an important and innovative edict that separated trade from tribute. ${ }^{4} \mathrm{~A}$ distinction was made between traditional tribute vassal states that were still bound by the conventions of the tributary system and other non-tributary commercial countries that were now permitted to trade with China without having to go through the formality of sending an embassy. The tribute system remained, however, and the imperial audience represented its core ceremony (Wills, 2009 , p. 2) where visiting ambassadors or princes performed sangui jiukou, or 'three prostrations and nine knockings' (Rawski, 1998, p. 149) of the head (to the ground) before the emperor. ${ }^{5}$ Trade with vassal states such as Siam, for example, continued to operate at the diplomatic level and was permitted only at times of periodic missions to the Qing court to pay tribute. General, non-tributary trade and maritime trade with Southeast Asia now fell entirely into the hands of Chinese native private traders who were allowed to travel and trade abroad (Wills, 2009, p. 2). ${ }^{6}$

A number of Chinese ports were now opened to European trade including Shanghai, Ningbo, Dinghai, Wenzhou, Quanzhou, Chaozhou and Xiamen (Zhao, 2013, p. 111). English ships started arriving in greater numbers by the late seventeenth and early eighteenth centuries seeking Chinese luxury goods for a growing English market, but their numbers were still very small as evidenced by the fact that in 1723 , for example, only four British ships visited Canton (Howard, 1994, p. 24). ${ }^{7}$ This number is in stark contrast with the growth of a massive Asian junk trade carried on throughout Chinese ports by native Chinese traders and sailors-a fact often lost sight of in Western historical accounts given their emphasis on European trade with China at this time.

4 Evelyn Rawski (1998, p. 198) pointed out that the Qing were quick to demonstrate they were prepared to carry on Ming state rituals.

5 The British referred to the kowtow ceremony as 'san-kwei-kew-kow', referred to as 'thrice kneeling and nine times bowing the head to the ground' (Ellis, 1817, p. 124).

6 Thai traders of Chinese ethnicity soon learned how to circumvent the official rules and traded openly to China as 'Chinese natives' using Chinese-style junks (Cushman, 1993, p. 129).

7 The Macclesfield, an English ship, returned from Canton with a cargo of Chinese products in the 1699-1700 season that was responsible for creating a demand for Chinese luxury products (Howard, 1994, p. 22). 


\section{The Canton Trade System}

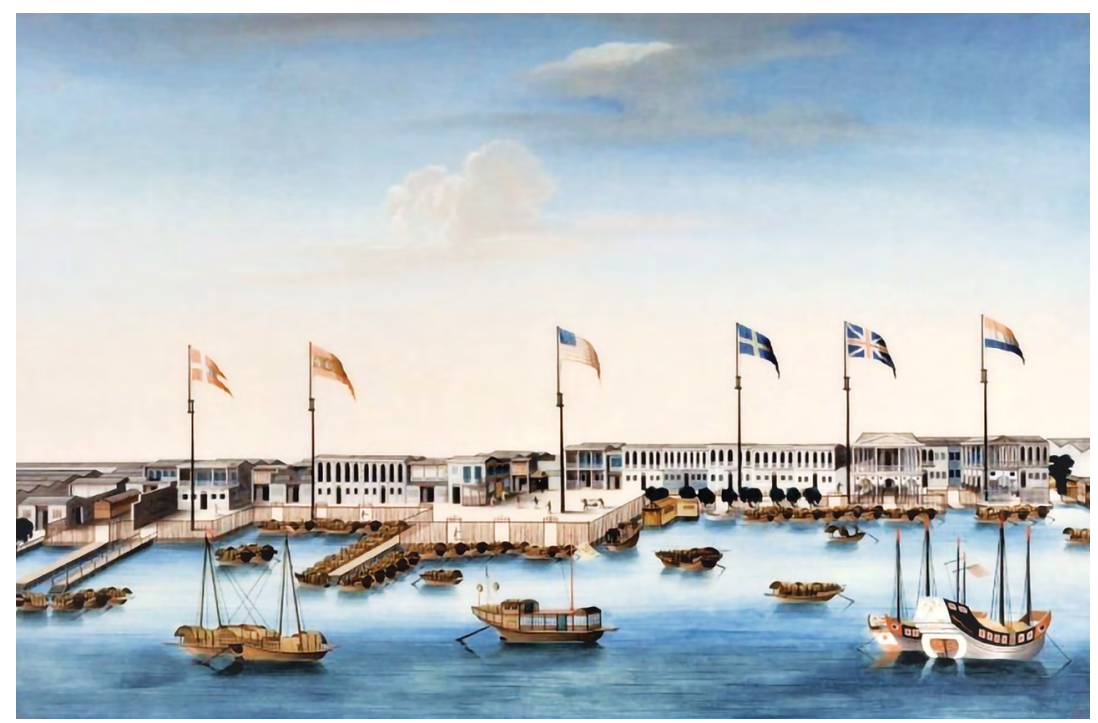

Figure 2: Painting by an unknown Chinese artist of the foreign factories or 'hongs' on the Canton waterfront in 1805 showing the location of the British factory situated between the Swedish and Dutch factories.

Source: Wikipedia Commons.

The growth of the chinoiserie craze in Europe, and especially in Britain, in the first half of the eighteenth century saw a rapid increase in the number of European ships arriving annually at Chinese ports. ${ }^{8}$ The Qianlong emperor responded and, by 1760 , edicts had been issued aimed at containing, controlling and regulating Western trade with the Chinese empire, which remained in effect until the signing of the Treaty of Nanjing in 1842 at the settlement of the First Opium War. Referred to as the 'Canton trade system' by Western historians, the decree laid down several stipulations for Western trade. ${ }^{9}$ Trade was confined to the port of Canton and permitted only between November and March, after which all Western traders had to retire to the Portuguese settlement of Macao or return to Europe. Western merchants, known as supercargoes, were restricted to a six-acre enclave, measuring 400 yards in length and 300 yards in width, on the riverfront

8 See Van Dyke (2007) for a comprehensive history of Chinese trade with Western nations.

9 For a full account of these regulations, see the Memorial dated 1759 written by the governorgeneral of the Liangguang provinces, Li Shiyao, on 'Five Rules to Regulate Foreigners' in Li (1969, pp. 29-34). 
in the suburbs of southwest Canton where they lived and worked in their respective warehouses or national Factories. ${ }^{10}$ They were forbidden to enter the walled city of Canton and foreign women were not allowed. Westerners were forbidden to learn or speak Chinese and all communication between them and the Chinese Government was conducted only through officially appointed Chinese linguists. The reliability and truthfulness of the linguists in translating Western concerns and grievances was often suspect, but European traders had no other mechanism for reporting these to the Chinese Government. A major grievance was the fact that Western traders were not protected by a formal treaty governed by rights and obligations, nor was there any certainty that guaranteed their continuing presence at Canton. Further, periodic transgressions of Chinese law by British sailors caused serious disputes between the provincial government and Company officials who were understandably opposed to Englishmen being judged and sentenced by Chinese law.

The relationship between the Select Committee of the Company, which held the British tea monopoly and formed the major British merchant institution in China, and local authorities was critical for the wellbeing of trade at Canton. The provincial government was in the charge of the governor-general or viceroy who presided over the provinces of Guangdong and neighbouring Guangxi, and who worked in association with the viceroy of Canton (Cranmer-Byng, 1962, p. 8). The most important figure from the Company's Select Committee's perspective was the Hoppo, or chief superintendent of customs, who worked independently of the viceroy and was the emperor's financial representative at Canton. The Hoppo was appointed for three years, having purchased his commission at the imperial court. Cranmer-Byng (1962) adds that:

During his term of office [the Hoppo] would have to remit considerable sums of money to the Imperial Treasury, to say nothing of magnificent 'presents' to the highest officials at Court: yet during his short period of office as Hoppo he usually managed to amass a fortune for himself. (p. 8)

10 A 'Factory' refers to a trading establishment in a foreign port and were also known as 'Hongs' in Canton (Conner, 2009, pp. 4-5). Factory buildings were leased from Chinese Hong merchants and built in a European style. The ground floor held the offices, storerooms or godowns, counting rooms and facilities for the 'compradore' and the servants. The compradore was responsible for food and other supplies for the Factory. The public rooms and dining rooms were situated on the first floor, while the private and sleeping accommodation of the Company members occupied the second floor. Teas were weighed, packed and sealed in crates and sent to the Company ships waiting at Whampoa (Crossman, 1991). 
The Hoppo oversaw the small group of licensed Hong merchants consisting of 12 members who formed themselves into an association known as the co-Hong (Cranmer-Byng, 1962, p. 12). All foreign trade at Canton was handled and controlled by co-Hong merchants whose members 'acted together under pressure from the local officials to ensure control over the foreign merchants' (Cranmer-Byng, 1962, p. 12). ${ }^{11}$ As a result of their role as the intermediaries between foreign merchants and the provincial government, Hong merchants were often caught in the middle between the demands of government officials or mandarins and those of the Company. Cranmer-Byng (1962) concludes that the actions of the provincial officials were critical for both the supercargoes and Hong merchants:

The Supercargoes were constantly afraid that the Co-Hong merchants would be used by the Canton officials as an even more efficient tool for 'squeezing' the foreign merchants. Its members were exposed to the greed and extortion of the local officials, especially the Hoppo and his crew, and bankruptcies were frequent. (p. 12)

Nevertheless, the historian Paul van Dyke has evaluated the Canton trade system as an extremely sophisticated and successful mechanism for controlling and regulating the great amount of Western trade conducted through Canton, where commerce flourished, foreign investment flowed into the port and foreigners 'were attracted to China in increasing numbers' (2011, p. 3). From the Company's perspective, however, the system became intolerable at times, specifically because the supercargoes were 'at the mercy of the whims of the local officials' and because they did not have any mechanism of appeal to the emperor (Cranmer-Byng, 1962, p. 13). ${ }^{12}$

11 Cushman (1993, p. 29) added that, in addition to the Hong merchants who were in charge of Western shipping, two other co-Hong merchants were delegated at this time; one was in charge of Siamese tribute and trade, and one was in charge of the native coastal trade from Fukien and Chaozhou arriving and departing at Canton.

12 This assessment applies to the period before the Macartney Embassy, but it will be seen that it was just as applicable at the time of the Amherst Embassy. 


\section{The Westphalian System of European Diplomacy}

A diplomatic exchange at the Qing court at the time of the Amherst Embassy was fraught with difficulties due to the difference in British and Chinese values and the institutional practices governing their respective diplomatic processes. The British approach was governed by the principles of the Westphalian system of diplomacy established in 1648 by the Treaty of Westphalia, which ended the Thirty Years War in Europe (Hampton, 2009, p. 116). ${ }^{13}$ Fundamental to its operation was the concept of all sovereign nation states, regardless of size or power, being treated equally under international law. The ambassador's main task was to uphold his sovereign's honour at a foreign court (Mattingly, 1995/2010, p. 211).

Westphalian diplomacy, according to the historian Tim Hampton, involves three forms of action governed by set customs, ritual and law. The first is negotiation, which is the chief function of the ambassador, where the role of language as the message transmitter is fundamental in cross-cultural exchanges in addition to the need to understand gestures and body language. Therefore, diplomacy is not only a cultural exchange, but also a site of 'linguistic negotiation' (Hampton, 2009, pp. 5-6). This process is the most fragile of political encounters. The British travelled to the Qing court in 1816 to appeal to the emperor and conduct negotiations that would place trade at Canton on a more reliable basis. Included in the ambassadorial party were a number of Mandarin-speaking Englishmen who it was hoped would facilitate this process.

The second form of action taking place within Westphalian diplomacy is mediation, which, in a Western context, refers to the axiom that the interests of one party affects the interests of all parties (Hampton, 2009, p. 8). Again, the British were hopeful that their goal of greater trade with China and subsequent economic gains would be recognised as beneficial to both parties.

13 This system saw 176 plenipotentiaries from 194 European rulers codify laws between sovereign states based on the principle of the law between nations (Hampton, 2009, p. 117). 
The third form of action is representation, which refers to the complex question of who, precisely, the ambassador is representing (Hampton, 2009, p. 8). This was a fundamental issue in the context of the Amherst Embassy where instructions were received from both the British Government and the Company Directors.

Ultimately, Western diplomacy centred on the principle that the person of the ambassador stood for the persona of the sovereign they represented when visiting another prince. An ambassador was invested further with political authority to speak on behalf of their sovereign at another court where the status of both sovereigns, in theory, was equal (Hampton, 2009, p. 10). Diplomatic locations were important sites of action and agency where an ambassador, while an intruder, had the inviolable right 'to travel to and from his destination' without being molested (Hampton, 2009, p. 75). This space was extremely difficult for the ambassador who was situated outside the geographical and legal confines of their own country and was dependent on the goodwill of foreigners for safe passage. Their power was endowed by those whom they represented and their reception depended on their host's recognition of the status of those who sent them. Both their behaviour and demeanour were important. Bodily appearance and actions, such as gestures, movements and dress, together with language were prescribed by protocols of reception and underpinned diplomatic engagements. Ultimately, an ambassador was judged by their hosts through the manner in which they presented themselves while representing another (Hampton, 2009, p. 9). The notion of the inviolability of the personage of an ambassador is a basic principle of Western diplomatic protocol. Their special status and that of their retinue renders the personnel of the embassy 'untouchable' and 'sacred' and serves to separate and isolate them from their host society. Individual perceptions and interpretations of the host society and culture made at the time of a diplomatic reception are governed by emotions formed under the pressures and outcomes of diplomatic encounters. The nature of Amherst's reception at the Summer Palace of Yuanmingyuan, it will be seen, was instrumental in the British reappraising their ideas of the Qing court and China. 


\section{The British East India Company ${ }^{14}$}

A distinction needs to be made between British trade with China conducted by private merchants, known as the Country Trade, and the members of the Company. Private merchants from India exported large quantities of textiles and brought opium into China. Silver received from these sales was, in turn, exchanged for bank notes issued by the Company and drawn on banks in India and London. In the absence of a Chinese demand for British goods, tea could only be procured with payment in silver. The principal business of the Company was its highly profitable monopoly of the tea trade, which was reaffirmed in 1813 at the time of the British Parliament renewing the Company's charter (Morse, 1926/1966, vol. 3, p. 204). ${ }^{15}$ Taxes from the sale of tea paid an estimated $£ 4$ million into the coffers of the British Government at the time of the Amherst Embassy (Staunton, 1822, p. 167).

The British East India Company was an amalgamation of two companies formed in 1708, namely, the joint-stock 'Governor and Company of Merchants of London Trading to the East Indies' formed in 1600 and the 'The English Company Trading to the East Indies' founded in 1698. Known as 'The United Company of Merchants of England Trading into the East Indies', it henceforth controlled all direct trade between England and Asia. The Company was governed by a 24-member Court of Directors, elected by stockholders. Decisions were made at East India House, located in Leadenhall Street, London.

The Regulating Act of 1783 and India Act of 1784 placed the affairs of the Company under a Board of Control of six members appointed by the British Government in charge of overseeing the governance of India. The head of the board during discussion on the inception of the Amherst Embassy was Lord Buckinghamshire, who died of a heart attack two days before the mission departed Portsmouth for China. ${ }^{16}$ His place was taken by George Canning, one of Amherst's closest friends. The Company's management at Canton was conducted by a three-

14 Specific references on the British East India Company at Canton include Bowen (2006), Greenberg (1969), Keay (1991), Philips (1940), Van Dyke (2007) and Wakeman Jr (1978). For an in-depth study of the Company in India, see Dalrymple (2019).

15 Trade between England and India was opened to free traders at this time.

16 Buckinghamshire had been in ill health and had taken the waters at Bath in the week preceding his death. He died while riding in Hyde Park (Charles Grant to Amherst, 13 April 1816, in BL IOR MSS EUR F 140/38 (a)). 
member Select Committee headed by the president of the committee. Extraordinary matters concerning Company ships or decisions on the dispatch of an embassy were managed by a small Secret Committee of three or four members sitting in London. Their instructions to the Select Committee at Canton were relayed via the ships of the season, which took six months to reach their destination. Therefore, the turnaround for responses and reporting on the latest developments was 12 months.

The British Factory at Canton housed 22 members in 1812. ${ }^{17}$ These included eight supercargoes and three writers. Supercargoes were responsible for the 'Indiamen' that anchored each trading season at the island of Whampoa, 12 miles downstream from Canton. In 1812, these numbered between 20 and 30 ships whose respective crews added up to thousands of British sailors who visited the European enclave of Canton on leave and were often involved in altercations with local people. The smooth operation of the trade was dependent on relationships 'either direct or indirect, verbal or by letter' between the members of the Company Select Committee and the provincial government (Staunton, 1822, p. 196). Many of the earlier restrictions imposed by the Canton system had been relaxed by 1815 , but serious altercations arising from the Anglo-French war played out in the waters of the Pearl River, inevitably arousing Chinese mistrust and suspicion of British actions and motives in this trade-rich maritime environment.

\section{The Pearl River Setting}

Western ships coming to trade at Canton stopped outside Macao where captains were issued with a permit and allocated a Chinese pilot who navigated the ship to its up-river anchorage at Whampoa. The island of Lingding was the first notable landmark seen after leaving Macao and was important as the designated mooring place for foreign warships, which were prohibited by Chinese law from proceeding any further into the Pearl River Delta.

17 Apart from the three members who made up the Select Committee, others were in charge of weighing teas, keeping the books and copying Consultation Books. Also included was an inspector of teas, Samuel Ball, and his assistant; a surgeon and his assistant; and the Reverend Doctor Robert Morrison, translator and teacher of Chinese (Morse, 1926/1966, vol. 3, pp. 176-177). 


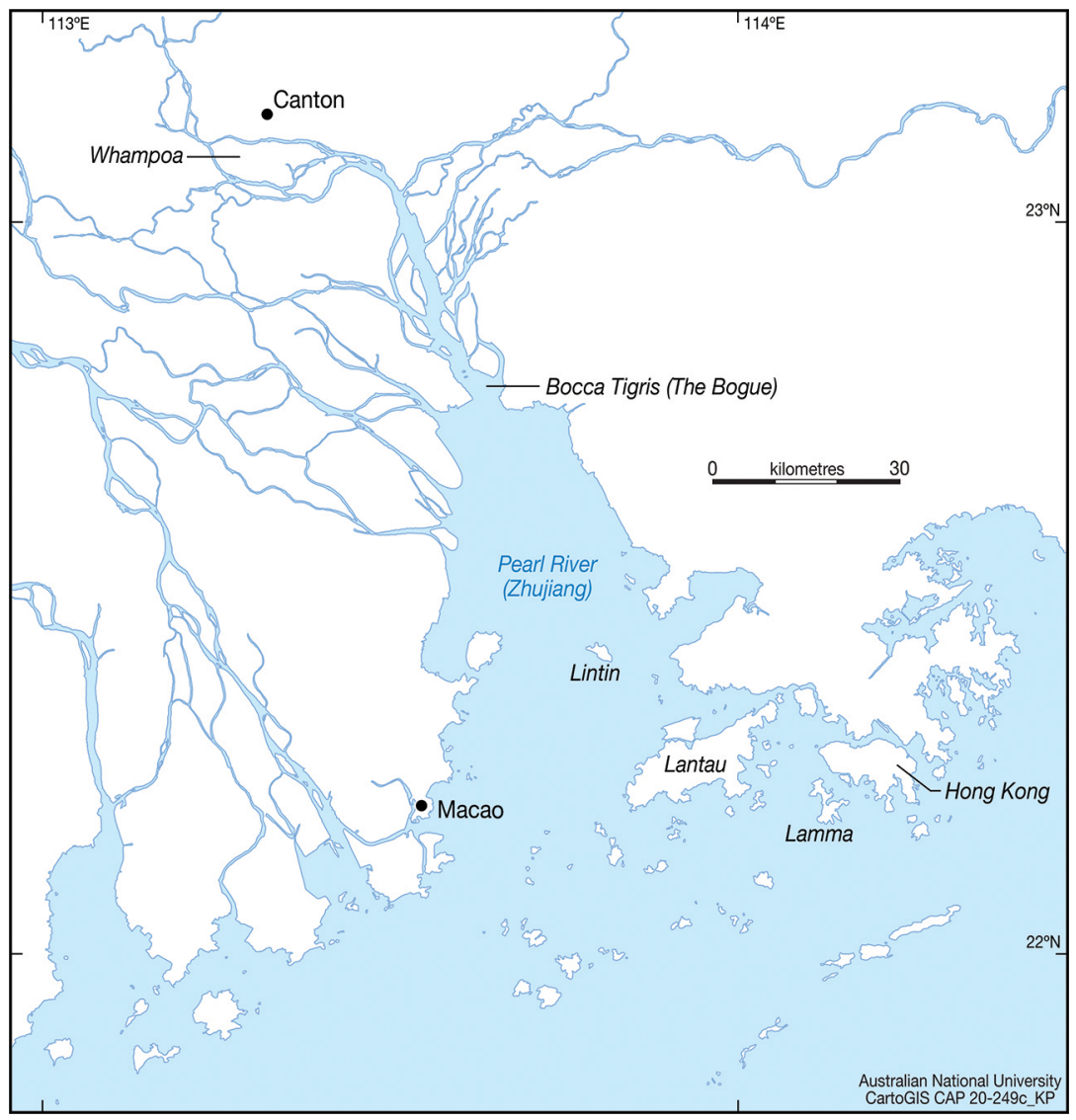

Figure 3: Map of the Pearl River estuary showing the locations of Macao, the Bocca Tigris and Whampoa island where Western ships anchored and loaded cargoes.

Source: CartoGIS, College of Asia and the Pacific, ANU.

The route to Canton commenced at the narrows of the Pearl River situated at the northern end of the estuary called the Bocca Tigris ('Tiger's Mouth') or the 'Bogue', which was guarded by three Chinese forts at its entrance. ${ }^{18}$ The deterrent power of the forts for British warships was minimal. Commodore George Anson was suitably dismissive when visiting Canton during his voyage around the world in 1741-1742, and wrote of a 'motley band' from one of the forts who tried unsuccessfully to stop his illegal entry into the river (1790).

18 One fort was situated on two west-lying islands, while the other two sat at the foot of a larger island on the eastern side of the Bogue (Conner, 1997, p. 21). 
Navigation on the Pearl River was difficult due to numerous sandbars, tidal patterns and thousands of junks housing Tanka families and others engaged in the vast domestic coastal trade that crowded the river. Arrival at Whampoa revealed the sight of Western ships at anchor surrounded by sampans engaged in the unloading and loading of cargoes, especially tea. A British naval officer, James Johnson, who visited Canton in 1804, described the scene in terms coloured by national pride:

In viewing the various national flags flying on board their respective ships at Whampoa, it is highly gratifying to Englishmen's feelings, to observe the British, superior in numbers to all others collectively; while each individual ship, like a colossal emblem of the British commerce, appears to look down with contempt on the pigmy representatives of other nations that surround her. (1806, p. 63)

Johnson approached Canton at night and marvelled at the lights of the city and the number of boats surrounding the foreshore, as well as:

The din of the Chinese language on every side; the clangour of their gongs, the shrill noise of their music, the glare of their fire works, all combine to form a scene so novel and striking, that the impression which it leaves on one's memory, can hardly ever be erased afterwards. (p. 65)

His arrival at the wharf outside the British Factory at Canton evoked a greater reaction. Johnson used italics to describe a scene where 'the inhabitants, language, manners, customs, even the houses, [and] manufactures' were 'so specifically different' from what he had seen before that he 'could almost fancy' himself 'transported into a new world' (p. 65).

\section{Political-Military Factors: The Macao Expeditions of 1802 and 1808}

A fundamental historical difference between the Macartney Embassy and Amherst Embassy was that the latter took place at the conclusion of a period of total war. International conflict arising from British wars with France and her ally Spain resulted in tensions being played out in Chinese territorial waters. An expedition of French and Spanish warships threatened Company ships in 1799, resulting in the introduction of a convoy system conducted by the Royal Navy that escorted British ships to St Helena (Wood, 1940, p. 139). A treaty signed between France and 
Portugal, which henceforth closed all Portuguese ports to British ships, prompted the governor-general of Bengal in 1802 to send six British warships carrying an expeditionary force of Indian Sepoys to occupy Macao to prevent the settlement falling into French hands, which would have had disastrous effects for Company trade (Wood, 1940, p. 139). ${ }^{19}$ The Portuguese authorities objected, fearing that Macao 'would be lost forever' if they accepted British assistance (Wang, 2014, p. 236). ${ }^{20}$ British troops were denied permission to land and the Jiaqing emperor, understandably suspicious of British intentions, ordered the immediate departure of the troops from Chinese waters. The British refused, their ships remained anchored near Macao and trade was suspended. News of peace between Britain and France following the Treaty of Amiens (1802) reached Macao soon afterwards and the troops withdrew. ${ }^{21}$ British actions, however, had sent a clear message to the emperor of their willingness to act decisively and use military force, if necessary, to safeguard the Canton trade. The Jiaqing emperor had been alarmed but, according to Wang (2014), was reassured by reports from Macao that 'no foreign countries, including Britain, could menace the dynasty' (p. 237). ${ }^{22}$ The Portuguese at Macao also stepped up their campaign of spreading invidious reports of British intentions on the settlement at this time, alerting the Chinese Government to their 'captious and deceitful' intentions while masquerading as mere traders (Wood, 1940, p. 144).

A more serious dispute arose between the British and local Chinese authorities due to the British military occupation of Macao in 1808. Executed in response to a potential French threat as well as rampant local pirate activity in the Pearl River that threatened Company shipping and personnel, the governor-general of Bengal sent Admiral Drury with 300

19 The British had learned as early as 1778 that France and Portugal had held negotiations for the cession of Macao to France. For a full account of problems at Macao due to British military action in 1802 and 1808, see Wang (2014, pp. 236-244).

20 The Portuguese had been permitted to establish a trading base at Macao in 1557 and remained the only Europeans with a foothold in China until the Treaty of Nanking (1842) following the First Opium War ceded the island of Hong Kong to Britain.

21 Wood (1940) wrote that news of the treaty saved the Select Committee from making a 'catastrophic' decision as Wellesley, governor-general of Bengal, was about to send instructions to seize Macao by force. This would have placed the committee in an untenable position. Wood contended that Wellesley's order would not have been obeyed, as to do so would have confirmed Chinese suspicions of British intentions and placed the English in 'just as bad a light as the French' (p. 143).

22 The Jiaqing emperor's assessment is in stark contrast to his great grandfather, the Kangxi emperor, who stated with great foresight in 1716, 'Certainly ships from Western countries may sail to China if they wish, though I suspect that the countries in the Western Ocean will become a threat to China in one hundred years' (as quoted in Zhao, 2013, p. 153). 
troops to occupy Macao. ${ }^{23}$ Arriving on 11 September 1808 without prior notice to either the Chinese or Portuguese authorities, the troops were refused permission to land whereupon Drury took matters into his own hands and ordered their occupation of Macao on 21 September ( Fu, 1966, vol. 2, p. 603). Following a series of complicated negotiations between the Select Committee and local government, trade at Canton was stopped on 8 October (Wood, 1940, p. 148). Drury endeavoured to arrange a meeting with the viceroy of Canton to resolve matters and to explain the British position, but his overtures were rejected. In response, Drury illegally entered the Pearl River in three heavily armed vessels, endeavouring to intimidate the Chinese to lift their embargo on trade. When this failed, he set off for Canton in an effort to meet the viceroy (Wang, 2014, p. 242). Nearing Canton, Drury found his passage blocked by Chinese war junks holding thousands of troops who fired on him and his military escort. A British soldier was injured, but Drury's order for his troops to return fire was not heard and he decided to withdraw at this time and retreated down river. He claimed later that he had held back deliberately, telling the president of the Select Committee:

I never would consent to the slaughter of these defenceless multitudes [the people of Canton]; but if their commerce required to be supported by hostilities, and that if a single seaman of mine was killed, I would level Canton to the ground. (as quoted in Barrow, 1817b, p. 416)

Meanwhile, Chinese troops had massed around Canton and Macao with orders to set fire to British ships anchored at Whampoa and Macao. After further protracted negotiations, Drury decided to depart and withdrew his troops from Macao. Claiming a victory over the Royal Navy, the Chinese erected a pagoda to commemorate their success.

The Jiaqing emperor, angered by British actions, issued an edict condemning the occupation as an affront to Chinese sovereignty and dismissing British fears of a possible French invasion of Macao. Any aggressive French action, the emperor declared, would be met with Chinese military force where 'we would immediately send our mighty army to suppress and annihilate them in order to maintain our maritime

23 Wang (2014) wrote of the piracy threat, 'By the end of 1808, the pirate confederation even threatened to attack Canton after destroying almost half of the Qing fleet in Guangdong' (p. 240). Foreign merchants travelling between Macao and Canton were in constant danger of being attacked and had to be escorted by armed guards. 
defence' (Imperial edict dated 14 November 1808 in Fu, 1966, vol. 1, p. 372). Regardless of the emperor's grandiose claims, Chinese concerns about British strategic intentions towards China had firmly registered. This fear, according to the British historian Herbert Wood (1940, p. 139), was the reason for the Jiaqing emperor's stand against Amherst.

\section{British Nationalism and the Monarchy}

The period between the Macartney and Amherst embassies (1793-1816) saw fundamental changes in Britain with the growth of nationalism centring on a veneration for the institution of the British monarchy. Historians have noted the construction of a patriotic identity that was inextricably connected with George III as the 'father' of the nation in which 'affection for the monarch' became a crucial test of British identity (Russell, 1995, p. 5). Explained largely as a response to the shock attack on the French monarchy during the French Revolution, Linda Colley (1984) wrote that celebrating the British monarch was 'a way of celebrating the nation's liberty as against the military despotism of France and the subservience of her satellite nations in Europe' (p. 121).

British victory over France in 1814 and, ultimately, in 1815, promoted Britain to the rank of the world's leading power. A shift in British values and concerns is reflected in the difference between the choice of personnel of the Macartney and Amherst embassies. The Macartney Embassy, which included scientists, mathematicians and other representatives of the sciences and technology, represented enlightenment concerns with the rational collating and measuring of cultural differences and artistic practices (Clingham, 2015). Eastberg (2009, pp. 39-46) argued that Staunton remained a man of the enlightenment due to his peculiar education in the classics and sciences. The other men of the Amherst Embassy, which included a large contingent of Company men from Canton, more closely reflected Regency values and were concerned primarily with pragmatic and material interests founded on commerce, signifying Britain's ascendency in manufacturing and trade, as well as a commitment to duty and respect for the institution of the British monarchy. Amherst, it will be seen, was above all a courtier of St James's; his paramount loyalty was to his sovereign whose honour had to be defended at all costs. Further, his time at St James's and earlier posting at the Italian court of the Two Sicilies (1809-1811) had given him firsthand experience of European courtly 
protocols and procedures. Amherst, unlike Macartney who had been governor of Madras, had no prior experience of eastern courts but came to the Qing court well versed in English and Continental court protocol, confident in the knowledge that he was the representative of the sovereign of the world's greatest power and would be received with honour. The importance of rank and honour for governing British behaviour in early nineteenth century aristocratic and military culture has been pointed out by historians (e.g. Bell, 2008, p. 36). Amherst, it will be seen, was not disposed to be relegated by his Chinese hosts to the inferior status of a tributary envoy from a vassal state.

Insight into British thinking on the connection between diplomacy and commerce at the time of the Amherst Embassy is found in Robert Morrison's (1820, p. 7) introductory remarks to his memoir of the Amherst Embassy. Morrison contended that improvement and progress for both individuals and independent nations was founded on an amiable intercourse with each other based on the principles of international law. ${ }^{24}$ Governments who aspired to this goal while pursuing the good of their own country deserved the 'thanks of Mankind' (Morrison, 1820, p. 7). Commercial intercourse fostered the improvement of the 'temporal condition' of all, but only if it was conducted on the basis of equality and mutual reciprocity (Morrison, 1820, p. 8). Because the products of the earth were not evenly distributed between countries, it was the duty of governments to exert their influence on the leaders of other nations to alert them to the benefits of trade. Trade benefitted the farmers and manufacturers of all countries engaged in commerce, resulting in mutual improvement and progress.

Such beneficial results were possible only under conditions founded on equality and reciprocity, free of the control of slave owners or despotic lords: "The idea that one owes and yields homage to the other is likely to be prejudicial to the fair commercial intercourse between the two nations' (Morrison, 1820, p. 8). The Chinese custom of the kowtow, if not mutually reciprocated, expressed in the strongest manner 'the submission and the homage of one person or state to another'. Morrison concluded that it should be carried out only by those European nations who 'consider themselves tributing and yielding homage to China'

24 Staunton (1821) wrote that because the Chinese were 'surrounded by barbarous tribes, and in great measure protected from their incursions by natural boundaries, they have neither had occasion for, nor the opportunity of learning, any of the principles of that inter-national law' (p. vi). 
(Morrison, 1820, p. 8). The British Government, however, acted as every civilised government should act when endeavouring to cultivate a good understanding and liberal intercourse with China, and would never yield homage to China (Morrison, 1820, p. 8). British identity in this period was based on a strong belief in liberty, the institution of Parliament and the perceived rationality of the British people. David Armitage (2000) described the ideology of the British people at this time as one founded on Protestant values, the idea of progress and the freedom of maritime commerce. Porter similarly demonstrated that the British held the ideal of a healthy and unobstructed commerce, protected and encouraged by the state, leading to progress and economic wellbeing (Porter, 2001, p. 201). These categories, representing the British paradigm of the time, were the antithesis of Chinese values and attitudes and inevitably formed the context in which the British judged Qing control of society, commerce and trade (Porter, 2001, p. 201). British views of Chinese indifference to foreign trade, and their confinement of the British to the port of Canton, described by Staunton (1822, p. 192) as 'a frontier town, on the remotest verge of the Asiatic continent' where they lived under 'a highly jealous, despotic, and arbitrary' government, inevitably created severe tensions and cultural clashes between the British and Chinese. The part these tensions played in giving rise to proposals for the dispatch of another British embassy to China is outlined in the following chapter. 
This text is taken from Britain's Second Embassy to China: Lord Amherst's 'Special Mission' to the Jiaqing Emperor in 1816, by Caroline Stevenson, published 2021 by ANU Press, The Australian National University,

Canberra, Australia.

doi.org/10.22459/BSEC.2020.02 